\begin{tabular}{|c|c|c|}
\hline Received: March 2019 & Accepted: April 2019 & Published: April 2019 \\
\hline \multicolumn{2}{|c|}{ Article DOI: http://dx.doi.org/10.24903/sj.v4i1.282 } \\
\hline
\end{tabular}

\title{
Investigating the Relationship between Test-Taking Anxiety and Test- Takers' Performance on the IELTS Test
}

\author{
Dang Arif Hartono \\ Universitas Agung Podomoro \\ dang.hartono@fulbrightmail.org
}

\begin{abstract}
Although there is a growing body of research indicating that anxiety relates to foreign language learning, the correlation between anxiety and learners' performance on a high-stakes testing context has not been fully explored. To date, studies investigating the relationship between testtaking anxiety and test-takers' performance are not only limited in number, but also partial in nature as most of them only looked at one aspect of test-takers performance, i.e. listening, speaking, or writing performance only. This study is aimed at investigating the relationship between test-taking anxiety and test-takers' performance with a holistic view, taking into account the test-takers' performance on the listening, reading, speaking, and writing modules of the International English Language Testing System (IELTS ${ }^{\text {TM}}$ ) test. The participants in this study were 15 government officials taking an IELTS test preparation program. Two instruments were utilized in this study: (1) a set of test-taking anxiety questionnaire items to measure the level of anxiety and, (2) the official IELTS ${ }^{\text {TM }}$ test to measure test-takers' performance. The results indicated that there was a weak to moderate correlation between testtaking anxiety and the test-takers' performance across different modules of the IELTS test. These results corroborate the findings from previous studies.
\end{abstract}

Keywords: anxiety, test preparation, IELTS, high-stakes test 


\section{INTRODUCTION}

Anxiety is one of the topics in second and foreign language learning that has been continually researched. It can be traced back to the end of 1970s when Scovel (1978) argued that anxiety could be facilitating or debilitating language learning and proposed that the construct should be specifically defined to distinguish it from the general 'affect' construct commonly used by the researchers of the era. Research on the topic then increased in quantity after (Horwitz, Horwitz, and Cope (1986) developed Foreign Language Classroom Anxiety Scale (FLCAS) and identified three causes of anxiety: communication apprehension, test anxiety, and fear of negative evaluation.

Since then, numerous studies expanded the scope of the research on anxiety by investigating the association between anxiety and various dimensions of learners' performance and types of language skills. For example, Phillips (1992) conducted a study to find out the relationship between anxiety and learners' oral test score and found that anxiety had a moderate, negative correlation with oral test results. Aida (1994) examined the extent to which anxiety experienced by American learners of Japanese correlated with their final grade. She found that anxiety had a moderate, negative association with the course grades. Similarly, Saito and Samimy (1996) carried out a research which confirmed a moderate, negative correlation between anxiety and final grade in a Japanese course. In their studies, Saito, Garza, and Horwitz, (1999) also found that there was a negative correlation between anxiety and reading comprehension among learners of Japanese, French, and Russian.

In a similar vein, Criado and Mengual (2017) looked into the relation between anxiety and English speaking test scores among native speakers of Spanish and found that both variables were negatively correlated. Sutarsyah (2017) conducted a study in which he also found a moderate, negative correlation between anxiety and speaking performance among Indonesian students.

In the area of listening comprehension, Elkhafaifi (2005) investigated a relation between anxiety and listening comprehension grades from 233 learners of Arabic in an American university and the results indicated that there was a significant, inverse correlation between the two variables. Similar result was also found in writing. Rodríguez-Sabiote, Serna-Quiles, Álvarez-Rodríguez, and Gámez-Durán (2017) conducted a study to identify a relationship between anxiety and language learners' writing performance. The results of their study indicated that there was a moderate, negative correlation between anxiety levels and learners' performance on the writing test. 
These studies seem to point to the same direction: anxiety correlates negatively with learners' performance in all language skills (i.e., listening, reading, writing, and speaking). However, there is an important point to note. Most of these studies concerned about learners' anxiety in a language classroom or measured learners' performance using instruments that are low-stakes in nature (e.g., course grades, self-made tests, etc.). While these studies undoubtedly provide important information for improving language teaching and learning in the classroom, their results may not offer information needed to fully understand the relation between anxiety and language learners' performance in a context where a high-stakes test is used to make a decision. Such understanding is crucial because nowadays the use of high-stakes testing is pervasive and the result of high-stakes tests has become a standard reference for authorities to make decisions in life-changing situations, such as college admission, immigration, recruitment, promotion, etc.

Another important point to note is that most of these studies utilized the FLCAS. In'nami (2006) pointed out that the number of items measuring test anxiety in the FLCAS is very limited (only 3 out of 33 items in the questionnaire). With a very small number of items measuring test anxiety in the FLCAS, it is "very difficult to measure the construct of test anxiety appropriately" (In'nami, 2006, p.320). Thus, one cannot simply assume that anxiety would negatively correlate with learners' performance in a high-stakes testing context only because some studies have proven that anxiety correlates negatively with learners' performance in language classrooms or low-stakes testing situations.

To date, studies that investigated anxiety specific to testing context are both limited in number and partial in nature because most of them only investigated test anxiety and its relation to one particular skill (e.g. reading, listening or writing only). In a study involving 63 Iranians learning for IELTS test, Golchi (2012) found that listening anxiety correlated negatively with listening comprehension. Serraj and binti Noordin (2013), in their study with participants of 210 Iranian EFL students, discovered a moderate, negative association between anxiety and the participants' performance on an IELTS-like listening test. Similarly, using test-taking anxiety questionnaire and two listening tests from Cambridge IELTS 8 book to measure the anxiety and performance of 63 participants, Winke and Lim (2017) also found a negative correlation between test-taking anxiety and performance on the listening tests. In the area of reading comprehension, Tsai and $\mathrm{Li}$ (2012) found that reading proficiency of 302 EFL learners was negatively correlated to their test anxiety level. These studies resulted in a similar finding, indicating a negative association between anxiety and performance on a test. However, while 
these studies used IELTS-like tests as their instruments, none of these studies really captured the relation between anxiety and performance on a test in a truly high-stakes testing context. Therefore, to address this gap in the literature and to understand the relationship between anxiety and language learners' performance in a high-stakes testing, I conducted a study addressing the following question: To what extent does test-taking anxiety correlates with testtakers' performance on the IELTS test?

Unlike other previous studies in the literature, the current study is the first study that investigated the association between test-taking anxiety and IELTS test holistically, looking at the relation of test-taking anxiety to all modules (reading, listening, speaking, and writing) of the test as well as its overall score. Additionally, from the perspective of ecological validity, this study captures an authentic interaction between test-taking anxiety and test-takers' performance because the current study employed an official IELTSTM test to measure the participants' performance. Therefore, the results of the current study contribute to the growing body of research on test-taking anxiety by providing an information on how test-taking correlates to test-takers' performance in an authentic, high-stakes test.

\section{METHODOLOGY}

\section{Research Design}

To answer the research question, I conducted a correlational study investigating the relationship between one independent variable (test-taking anxiety) and five dependent variables (listening, reading, writing, speaking, and overall score on the IELTS $^{\mathrm{TM}}$ test). As there was no experimental treatment and random selection of participants was also not possible, the design of this study falls into the category of ex post facto research (Hatch \& Lazaraton, 1991; Turner, 2014). In ex post facto design, what becomes the main concern of the study is the relationship between variables and no treatment is given to the participants (Hatch \& Lazarton, 1991, p. 99).

\section{Participants and Procedure}

The participants were 15 government officials (12 males, 3 females) selected by the Ministry of Finance (MOF) as the recipients of the SPIRIT (Scholarship Program for Strengthening the Reforming Institutions) scholarship. The average age of the participants was 31.53 years old and all of them had completed an undergraduate degree. The MOF enrolled them in a long term, intensive preparation course, consisting of several components: General English course (1 month), TOEFL iBT® Preparation (3 months), IELTS ${ }^{\text {TM }}$ Preparation (1 month), and 
Academic \& Cultural Preparation (1 month). They attended classes for 8 hours per day and 5 days per week.

Upon completion of their IELTS preparation course, the participants took the IELTS test. Immediately after they completed the test, I asked them to complete test-taking anxiety questionnaire and, when the results of their IELTS test were ready, I gathered all necessary data and proceeded to data analysis.

\section{Data Collection and Analysis}

To measure the participants' anxiety, I used a test-taking anxiety questionnaire developed by Winke and Lim (2014). This questionnaire consists of 11 items measuring anxiety experienced by test-takers' using a 1-to-6 Likert-type scale. In addition, official IELTS ${ }^{\mathrm{TM}}$ test was used to measure the test-takers' performance in this study. The test was administered by IDP Indonesia as one of the IELTS ${ }^{\mathrm{TM}}$ testing centers in Indonesia.

As the data originated only from a small number of samples, I calculated the correlation between the variables using Kendall's tau-b $\left(\tau_{b}\right)$ correlation coefficient. Field (2009) asserted that Kendall's tau is better for a small data set since it produces a more accurate statistical calculation than Spearman's coefficient.

To improve the robustness of the statistical test, I utilized bootstrapping technique in calculating descriptive statistics and the correlation coefficient. This particular method was employed following the suggestions from LaFlair, Egbert, and Plonsky (2015), Larson-Hall (2015), and Plonsky, Egbert, and LaFlair (2015) who maintained that bootstrapping could be implemented to obtain robust statistics when researchers have to deal with issues like small samples and non-normal distributions. Table 1 below shows the specifications of bootstrapping employed in this study.

Table 1: Bootstrap Specifications

\begin{tabular}{ll}
\hline Sampling Method & Simple \\
Number of Samples & 10,000 \\
Confidence Interval Level & $95.0 \%$ \\
Confidence Interval Type & Bias-corrected and accelerated (BCa) \\
\hline
\end{tabular}




\section{FINDINGS AND DISCUSSION}

\section{Findings}

Theoretically, the range between the minimum and maximum scores for the test-taking anxiety lies between 11 and 66. As indicated by the data in the table 2, it is clear that the test-takers experienced a moderate level of anxiety $(M=39.20)$ during the IELTS test.

In the research question, I asked, "To what extent does test-taking anxiety correlates with test-takers' performance on the IELTS test?" The table 3 below summarizes the results of the statistical calculation carried out to address the question.

Table 2: Descriptive Statistics (with Bootstrapping) of the Observed Variables

\begin{tabular}{lcccccc}
\hline \multirow{2}{*}{ Variable } & $\boldsymbol{M}$ & $\begin{array}{c}\text { Lower } \\
\text { Bound }\end{array}$ & $\begin{array}{c}\mathbf{9 5 . 0} \text { Up } \\
\text { Bound }\end{array}$ & & & \\
& & 39.27 & 44.20 & 22.00 & 57.00 & 10.86 \\
\hline Anxiety & 39.20 & 34.27 & Max. & SD \\
Listening & 6.70 & 6.33 & 7.06 & 5.00 & 8.00 & .84 \\
Reading & 7.67 & 7.33 & 8.00 & 6.50 & 9.00 & .82 \\
Writing & 6.13 & 5.93 & 6.33 & 5.50 & 7.00 & .48 \\
Speaking & 6.27 & 6.00 & 6.57 & 5.50 & 8.00 & .68 \\
Overall Score & 6.83 & 6.57 & 7.10 & 6.00 & 8.00 & .65 \\
\hline
\end{tabular}

Table 3: Kendall's Tau-b ( $\left.\tau_{b}\right)$ Correlational Matrix between Variables (with Bootstrapping)

\begin{tabular}{lclllll}
\hline & Anxiety & Listening & Reading & Writing & Speaking & Overall \\
\hline Anxiety & - & $-.094(.645)$ & $-.310(.140)$ & $-.245(.247)$ & $-.335(.107)$ & $-.310(.135)$ \\
\hline \multicolumn{5}{c}{ Note: $p$-values are listed in parentheses after correlation coefficient }
\end{tabular}

The results indicated that there was a negligible negative correlation between test-taking anxiety and test-takers' performance on the listening module of the IELTS test $\left(\tau_{b}=-.094 ; p=\right.$ .645). The correlation between test-taking anxiety and test-takers' performance on the writing module of the IELTS was slightly higher but still considered a weak, negative correlation $\left(\tau_{b}=\right.$ $-.245 ; p=-.247)$.

The results further revealed that there was a moderate, negative correlation between testtaking anxiety and test-takers' performance on the reading module $\left(\tau_{b}=-.310 ; p=.140\right)$, speaking module $\left(\tau_{b}=-.335 ; p=.107\right)$, and overall score $\left(\tau_{b}=-.310 ; p=.135\right)$ of the IELTS test.

I find it important to discuss the obtained $p$-values as none of them was lower than the commonly used .05 cut-off point to be considered statistically significant. Larson-Hall (2012) argued that it is misleading to consider the results of a statistical test not statistically significant only because its effect size is higher that the arbitrarily set .05 cut-off point. She argued that: 
...it is perfectly legitimate for an author to put forth their case that with larger sample sizes, the $p$-value would likely be lower than the cut-off and thus there is at least a case to be made for the importance of the result (Larson-Hall, 2012, p. 249).

Therefore, following Larson-Hall (2012), I argue that the results - regardless of the high $p$ values for each observed variable - are worth reporting because, unlike previous studies on this subject, the result of this study provided an ecologically valid result since the test-takers' performance were based on official IELTS ${ }^{\mathrm{TM}}$ scores.

\section{Discussion}

The result indicated that correlation between test-taking anxiety and test-takers' performance on the listening module of the test was a weak, negative correlation. This finding is interesting because, on one hand, this contradicted the result of an earlier study conducted by Chang (2008), who found that there was a moderate-high correlation between anxiety and listening comprehension in a general classroom setting and a higher level of anxiety in a testing context. On the other hand, this result corroborated the findings from previous studies (In'nami, 2006; Winke \& Lim, 2014; Winke \& Lim, 2017). The possible reason why the anxiety level found in this study was low might have something to do with the nature of the preparation course. The test-takers' might feel less anxious because they had completed many exercises and practice sessions prior to the testing day. This might help them getting familiarized with the format as well as the pressure of the test, leading to a state of desensitization that made them no longer feel anxious about the test (Winke \& Lim, 2014). Put simply, there is a possibility that repetitive practices they had before taking the test familiarized them with the test and thus reduced their anxiety level. This is, of course, hypothetical and requires further investigations.

It was also found that there was a moderate, negative correlation between test-taking anxiety and test-takers' performance on the reading module of the IELTS test. This result is in line with what Tsai and Li (2012) found in their study using GEPT, a standardized English test commissioned by Taiwan's Ministry of Education. However, this finding becomes interesting when compared to the other variables in the study. The average score of the test-takers performance on the reading module is higher $(M=7.67)$ than the score on the listening module $(M=6.70)$, but the anxiety level test-takers' experienced on the listening module $\left(\tau_{b}=-.094 ; p\right.$ $=.645)$ is much lower than the anxiety level on the reading module $\left(\tau_{b}=-.310 ; p=.140\right)$. When viewed from this angle, this result seems to be counter intuitive. It is tempting to say this indicates that repetitive practices the participants had in the preparation course might not help 
in diminishing their test anxiety in the reading module. Yet, again, this is beyond the scope of this study and a well-designed experimental study with control groups is needed to answer this.

Test-taking anxiety and the test-taker's performance on the writing module correlated negatively $\left(\tau_{b}=-.094 ; p=.645\right)$. This corroborated Sarkhoush (2013) who also found a negative correlation between the two variables. This demonstrates that writing performance in the test is indeed associated with anxiety.

The test-takers' performance on the speaking module was found to be negatively correlated with test-taking anxiety. Huang and Hung (2013) also found a weak to moderate negative relationship between test anxiety and test-takers' performance on the independent speaking section of the TOEFL iBT. Woodrow (2006) investigated the association between anxiety and second language speaking performance among international students in Australia using an IELTS-based speaking test. Similar to this study, Woodrow also found that both variables were negatively correlated. These findings strengthen the notion that test anxiety and speaking performance are negatively correlated.

Finally, the overall score on the IELTS ${ }^{\mathrm{TM}}$ test correlated negatively on a moderate level with test-taking anxiety. As none of the studies in the literature used official IELTS ${ }^{\mathrm{TM}}$ or IELTSlike test as measure of learners' general proficiency, it is not possible to make a direct comparison of the result of this study to any other study. Nevertheless, this result indicated that test anxiety should be taken into account by test-takers' and test administrators as it is inversely associated with the test-takers' performance.

\section{CONCLUSION}

In general, the current study revealed that there was a weak to moderate negative relationship between test-taking anxiety and test-taker's performance on the IELTS ${ }^{\mathrm{TM}}$ test. As standardized tests like IELTS are often used as a decision making tool, it becomes important to make sure that its result truly reflects the test-takers' performance and, as much as possible, is absent from construct irrelevant variables like test-taking anxiety. Therefore, it is strongly suggested for test administrators to create non-threatening atmosphere and display hospitable behavior in proctoring the test. The possible consequences that comes from the result of the test already puts the test-takers' life at stake, so adding more pressure to it is perhaps not the wisest thing to do.

One obvious limitation from this study is the small number of the participants involved. While it is understandable because conducting an official IELTS ${ }^{\mathrm{TM}}$ test for a large number of people will be very costly, a high number of participants are still necessary to generate evidence 
that is more decisive. Another important point to note is that correlation is not causation and must never be considered as one. Therefore, a well-designed experimental study with a control group and a large number of samples is needed to determine whether test anxiety affects testtaker's performance in a high-stakes testing context.

\section{BIBLIOGRAPHY}

Aida, Y. (1994). Examination of Horwitz, Horwitz, and Cope's Construct of Foreign Language Anxiety: The Case of Students of Japanese. The Modern Language Journal, 78, 155-168. https://doi.org/10.1111/j.1540-4781.1994.tb02026.x

Chang, A. C.-S. (2008). Sources of Listening Anxiety in Learning English as a Foreign Language. Perceptual and Motor Skills, 106(1), 21-34. https://doi.org/10.2466/pms.106.1.21-34

Criado, R., \& Mengual, Y. (2017). Anxiety and efl speaking in Spanish compulsory and noncompulsory secondary education: A mixed-method study. Miscelanea, 55, 13-35. Retrieved from http://www.miscelaneajournal.net/index.php/misc/article/view/515/239

Elkhafaifi, H. (2005). Listening comprehension and anxiety in the Arabic language classroom. Modern Language Journal, 89, 206-220. https://doi.org/10.1111/j.15404781.2005.00275.x

Field, A. (2009). Discovering Statistics Using SPSS (3rd ed.). London: Sage Publications Ltd.

Golchi, M. M. (2012). Listening Anxiety and Its Relationship with Listening Strategy Use and Listening Comprehension among Iranian IELTS Learners. International Journal of English Linguistics, 2(4), 155-128. https://doi.org/10.5539/ijel.v2n4p115

Hatch, E., \& Lazaraton, A. (1991). The Research Manual: Design and Statistics for Applied Linguistics. Boston: Heinle \& Heinle Publishers.

Horwitz, E. K., Horwitz, M. B., \& Cope, J. (1986). Foreign Language Classroom Anxiety. The Modern Language Journal, 70, 125-132. https://doi.org/10.1111/j.15404781.1986.tb05256.x

Huang, H. T. D., \& Hung, S. T. A. (2013). Comparing the effects of test anxiety on independent and integrated speaking test performance. TESOL Quarterly, 47(2), 244-269. https://doi.org/10.1002/tesq.69

In'nami, Y. (2006). The effects of test anxiety on listening test performance. System, 34(3), 317-340. https://doi.org/10.1016/j.system.2006.04.005

LaFlair, G. T., Egbert, J., \& Plonsky, L. (2015). A practical guide to bootstrapping descriptive statistics, correlations, $t$ tests, and ANOVAs. In Advancing quantitative methods in second language research (pp. 46-77). Routledge.

Larson-Hall, J. (2012). How to Run Statistical Analyses. In Research Methods in Second Language Acquisition: A Practical Guide (pp. 245-274). Chichester: Wiley-Blackwell. https://doi.org/10.1002/9781444347340.ch13 
Larson-Hall, J. (2015). A Guide to Doing Statistics in Second Language Research Using SPSS (2nd ed.). A Guide to Doing Statistics in Second Language Research Using SPSS. New York \& Oxon: Routledge. https://doi.org/10.4324/9780203875964

Phillips, E. M. (1992). The Effects of Language Anxiety on Students' Oral Test Performance and Attitudes. The Modern Language Journal, 76, 14-26. https://doi.org/10.1111/j.15404781.1992.tb02573.x

Plonsky, L., Egbert, J., \& LaFlair, G. T. (2015). Bootstrapping in Applied Linguistics: Assessing its Potential Using Shared Data. Applied Linguistics, 36(591-610). https://doi.org/10.1093/applin/amu001

Rodríguez-Sabiote, C., Serna-Quiles, L., Álvarez-Rodríguez, J., \& Gámez-Durán, R. P. (2017). Do anxiety and English proficiency level affect writing performance in second language (L2) learning? Journal of English Studies, 15, 261-278. https://doi.org/10.18172/jes.3151

Saito, Y., Garza, T. J., \& Horwitz, E. K. (1999). Foreign language reading anxiety. Modern Language Journal, 83, 202-218. https://doi.org/10.1111/0026-7902.00016

Saito, Y., \& Samimy, K. K. (1996). Foreign language anxiety and language performance: A study of learner anxiety in beginning, intermediate, and advanced-level college students of Japanese. Foreign Language Annals, 29(2), 239-249. https://doi.org/10.1111/j.19449720.1996.tb02330.x

Sarkhoush, H. (2013). Relationship among Iranian EFL Learners' Self-efficacy in Writing, Attitude towards Writing, Writing Apprehension and Writing Performance. Journal of Language Teaching and Research, 4(5), 1126-1132. https://doi.org/10.4304/jltr.4.5.1126-1132

Scovel, T. (1978). The Effect of Affect on Foreign Language Learning: A Review of the Anxiety Research. Language Learning, 28, 129-142. https://doi.org/10.1111/j.14671770.1978.tb00309.x

Serraj, S., \& binti Noordin, N. (2013). Relationship among Iranian EFL students' foreign language anxiety, foreign language listening anxiety and their listening comprehension. English Language Teaching, 6(5), 1-12. https://doi.org/10.5539/elt.v6n5p1

Sutarsyah, C. (2017). An analysis of student's speaking anxiety and its effect on speaking performance. IJELTAL (Indonesian Journal of English Language Teaching and Applied Linguistics), 1(2), 143-152. https://doi.org/10.21093/ijeltal.v1i2.14

Tsai, Y.-C., \& Li, Y.-C. (2012). Test Anxiety and Foreign Language Reading Anxiety in a Reading-Proficiency Test. Journal of Social Sciences, 8(1), 95-103. https://doi.org/10.3844/jssp.2012.95.103

Turner, J. L. (2014). Using statistics in small-scale language education research: Focus on non-parametric data. Using Statistics in Small-Scale Language Education Research: Focus on Non-Parametric Data. New York \& Oxon: Routledge. https://doi.org/10.4324/9780203526927 
Winke, P., \& Lim, H. (2014). The effects of testwiseness and test-taking anxiety on L2 listening test performance: A visual (eye-tracking) and attentional investigation. IELTS Research Report Series, 3, 1-30. Retrieved from https://www.ielts.org/-/media/researchreports/ielts_online_rr_2014-3.ashx

Winke, P., \& Lim, H. (2017). The Effects of Test Preparation on Second-Language Listening Test Performance. Language Assessment Quarterly, 14(4), 380-397. https://doi.org/10.1080/15434303.2017.1399396

Woodrow, L. (2006). Anxiety and speaking English as a second language. RELC Journal, 37(3), 308-328. https://doi.org/10.1177/0033688206071315 